\section{Genetic Resistance to Scab Disease in Pecan}

\author{
Tommy E. Thompson ${ }^{1}$ and L.J. Grauke ${ }^{2}$ \\ Pecan Genetics and Breeding Research, Agricultural Research Service, U.S. \\ Department of Agriculture, Route 2, Box 133, Somerville, TX 77879
}

\author{
Additional index words. breeding, heritability, Carya illinoinensis, Cladosporium \\ caryigenum, host plant resistance
}

\begin{abstract}
Thirty-six cultivars and 948 seedlings from 15 controlled crosses in the U.S. Dept. of Agriculture-Agricultural Research Service pecan [Carya illinoinensis (Wangenh.) K. Koch] breeding program at Brownwood, Texas, were rated for susceptibility to nut scab [Cladosporium caryigenum (Ell. et Lang.) Gottwald] to determine heritability of this trait. Differences between parents and progenies, and within progenies, were highly significant. Within most families, a complete range of resistance reactions were evident, from fully susceptible to fully resistant. Heritability of resistance was determined by regressing individual progeny values on female, male, and midparent values, with the midparent heritability estimate being the highest $(0.54)$. This moderate level of additive gene action and the identification of superior parents in this study will contribute to the efficiency of breeding resistant cultivars.
\end{abstract}

Demaree (1924) stated that scab is "preeminently the most important pecan disease." It is caused by Cladosporium caryigenum and is today still the most devastating disease of pecan (Thompson and Grauke, 1991). Pecan production in the warm, moist, Gulf Coastal areas of the southeastern United States, where disease epidemics are common, would not be possible without some level of host plant resistance. Pecan cultivars are generally classified into two groups according to their susceptibility to scab: the resistant eastern and the susceptible western United States types. The level of resistance exhibited by some cultivars decreases over time, leading to the popular belief that cultivars "lose resistance," while in reality, the pathogen is adapting to the cultivar to overcome its resistance. Races of the scab fungus have been demonstrated, based on differential response of pecan cultivars to isolates of scab taken from four pecan cultivars (Demaree and Cole, 1929). When grown in vitro, the scab organism shows levels of genetic variation beyond that expected by mutation, indicating other mechanisms of asexual genetic recombination (Street, 1972). The ability of this imperfect fungus to form genetic variants would contribute to the observed ability of the organism to overcome some levels of host resistance over time (Cole and Gossard, 1956). KenKnight (1969) speculated that increased use of mechanical harvesting equipment during the 1960 s contributed to the spread of scab races, further contributing to the loss of cultivar resistance. Sanderlin (1992) documented the development of benomyl-resistant

\footnotetext{
Received for publication 13 Dec. 1993. Accepted for publication 6 May 1994. The cost of publishing this paper was defrayed in part by the payment of page charges. Under postal regulations, this paper therefore must be hereby marked advertisement solely to indicate this fact.

${ }^{1}$ Research Geneticist.

${ }^{2}$ Research Horticulturist.
} applications of that fungicide in a Louisiana orchard. Scab resistance in pecan is apparently a dynamic process involving the interaction of a genetically fixed cultivar under attack by a genetically plastic pathogen in an environment that can be manipulated (often unwittingly) by man to the benefit of either host or pathogen.

The average time from the initial cross until release of 19 U.S. Dept. of Agriculture (USDA) pecan scion cultivars has been 25 years. Given the time necessary to breed for scab resistance and the lag time of cultivar incorporation, an outstanding level of resistance is needed to ensure new cultivar adoption by the industry and the longevity of its resistance. The development of scab resistance has been a stated goal of the USDAAgricultural Research Service pecan breeding program since its inception (Crane et al., 1937). The objective of this research was to identify scab-resistant parental material to be used in the breeding program and to refine breeding strategies for the production of scab-resistant cultivars.

\section{Materials and Methods}

Genetic resistance of 36 cultivars (Table 1) was determined by rating trees growing in an orchard of historical cultivars adjacent to the nurseries of the USDA pecan breeding program at Brownwood, Texas. Cultivar clones were grafted in 1986 on established openpollinated 'Apache' rootstocks. Trees were replicated four times in a randomized complete-block design with single-tree plots spaced $10.7 \mathrm{~m}$ each way. The average of the four plots was used as each parental value.

Progenies studied were from the USDA pecan breeding program mentioned above. Clones were selected as parents based on yield, precocity, nut quality, disease resistance, and desirable tree characteristics. Seeds from con- trolled crosses (Smith and Romberg, 1940) were planted directly in the field or were planted in the greenhouse and transplanted to the field after one season. No replicated experiment design was used with respect to establishment of these seedlings. Seedlings of the same family (common female and male parent) were usually grouped in areas of the nursery, according to year and cross, and spaced $4.6 \times 2.1 \mathrm{~m}$. The methods of data collection appear to be free of bias, and a sufficient number of seedlings was analyzed to provide reasonably accurate determinations. Seedling age ranged from 6 to 15 years. No fungicides were ever applied to these trees.

Prevalence of scab infection was high at Brownwood in 1992 due to unusually high rainfall (1184 $\mathrm{mm}$ recorded on the station vs. $655 \mathrm{~mm}$ normally received in this area). In most years, scab is not severe enough to differentiate cultivar susceptibility at this location.

Nut scab resistance was determined by rating individual trees using the 1-5 scale developed by Hunter and Roberts (1978). Nuts throughout the canopy were inspected until the most severe expression of scab was found. Those nuts were rated into classes where $1=$ completely free of scab; $2=$ a trace to $10 \%$ of
Table 1. Pecan nut scab ratings for 36 cultivars at Brownwood, Texas, in 1992. Ratings made according to the scale of Hunter and Roberts (1978), where $1=$ most resistant.

\begin{tabular}{|c|c|}
\hline Cultivar & Rating \\
\hline Apache & $5.0 \mathrm{a}^{\mathrm{z}}$ \\
\hline Wichita & $5.0 \mathrm{a}$ \\
\hline Burkett & $5.0 \mathrm{a}$ \\
\hline Western Schley & $5.0 \mathrm{a}$ \\
\hline Tejas & $4.0 \mathrm{ab}$ \\
\hline Cherokee & $4.0 \mathrm{ab}$ \\
\hline Comanche & $4.0 \mathrm{ab}$ \\
\hline Cheyenne & $3.5 \mathrm{bc}$ \\
\hline Mahan & $3.3 \mathrm{~b}-\mathrm{d}$ \\
\hline Shawnee & $3.0 \mathrm{~b}-\mathrm{e}$ \\
\hline Sioux & $2.7 \mathrm{~b}-\mathrm{f}$ \\
\hline Pawnee & $2.5 \mathrm{c}-\mathrm{g}$ \\
\hline Shoshoni & $2.5 \mathrm{c}-\mathrm{g}$ \\
\hline Mohawk & $2.5 \mathrm{c}-\mathrm{g}$ \\
\hline Maramec & $2.5 \mathrm{c}-\mathrm{g}$ \\
\hline Forkert & $2.3 \mathrm{c}-\mathrm{g}$ \\
\hline Osage & $2.2 \mathrm{c}-\mathrm{g}$ \\
\hline Colby & $2.0 \mathrm{~d}-\mathrm{g}$ \\
\hline Barton & $1.7 \mathrm{e}-\mathrm{g}$ \\
\hline Peruque & $1.7 \mathrm{e}-\mathrm{g}$ \\
\hline Kiowa & $1.7 \mathrm{e}-\mathrm{g}$ \\
\hline Cape Fear & $1.7 \mathrm{e}-\mathrm{g}$ \\
\hline Podsednick & $1.7 \mathrm{e}-\mathrm{g}$ \\
\hline Choctaw & $1.7 \mathrm{e}-\mathrm{g}$ \\
\hline Chickasaw & $1.5 \mathrm{e}-\mathrm{g}$ \\
\hline Curtis & $1.5 \mathrm{e}-\mathrm{g}$ \\
\hline Desirable & $1.5 \mathrm{e}-\mathrm{g}$ \\
\hline Stuart & $1.5 \mathrm{e}-\mathrm{g}$ \\
\hline Caddo & $1.2 \mathrm{fg}$ \\
\hline Moreland & $1.2 \mathrm{fg}$ \\
\hline Sumner & $1.2 \mathrm{fg}$ \\
\hline Jackson & $1.0 \mathrm{~g}$ \\
\hline Success & $1.0 \mathrm{~g}$ \\
\hline Starking Hardy Giant & $1.0 \mathrm{~g}$ \\
\hline Gloria Grande & $1.0 \mathrm{~g}$ \\
\hline Melrose & $1.0 \mathrm{~g}$ \\
\hline
\end{tabular}

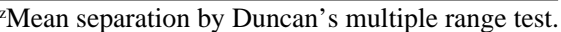
Ratings with a common letter are not significantly different $(\alpha \leq 0.05)$. 
the nut surface covered with scab lesions; $3=$ greater than $10 \%$ and $\leq 25 \%$ coverage; $4=$ greater than or equal to $25 \%$ and $\leq 50 \%$ coverage; and $5=$ greater than $50 \%$ of the surface covered by lesions.

PC SAS statistical procedures (SAS Institute, 1985) were used to analyze all data. Linear regression of each offspring's rating on its female, male, and the average rating of the parents (midparent value) was computed as a direct measure of heritability (Kempthorne and Tandon, 1953). Parent and midparent values were repeated for each progeny of each family (Latter and Robertson, 1960). The expectation for the regression coefficient of offspring on midparent is the ratio of $\mathrm{V}_{\mathrm{A}}: \mathrm{V}_{\mathrm{P}}$ or $\mathrm{h}^{2}$ $\left(1 / 2 h^{2}\right.$ for male or female parent $)$, where $V_{A}=$ additive genetic variance and $\mathrm{V}_{\mathrm{P}}=$ phenotypic variance. The covariance of offspring and midparent is $1 / 2 \mathrm{~V}_{\mathrm{A}}$, and the denominator for the offspring and midparent regression coefficient is $1 / 2 \mathrm{~V}_{\mathrm{p}}$. This calculation assumes that the contributions of epistatic interactions to covariance are negligible and that the phenotypic variance of the two parental populations are equal.

\section{Results and Discussion}

Examination of the data to evaluate the uniformity of scab pressure throughout the progeny nursery showed the presence of fully susceptible seedlings in all portions of the nursery.

A complete range of resistance to the race (or races) at the test orchard was noted in the cultivar test (Table 1). Some old cultivars (e.g., 'Success', grown since 1903, and 'Jackson', grown since 1917) exhibited excellent resistance. Other cultivars were highly susceptible (e.g., 'Apache', 'Wichita', and 'Western Schley') and should not be grown in humid climates.

Families with 10 or more progeny are presented in order of increasing levels of average resistance (Table 2). Most resistance classes were present in all families. Every family contained at least some extremely susceptible (class 5) progeny. Only three families ('Shawnee' x 'Cheyenne', 'Osage' $x$ 'Wichita', and 'Pawnee' $x$ 'Osage') contained no fully resistant (class 1) progeny. This lack of class 1 progeny could be due to few progenies in these families. These results agree with those of Roberts et al. (1977) who studied open-pollinated progenies of several maternal parents and found that most levels of resistance were found within each family.

Two-thirds of the progeny of the 'Wichita' $x$ 'Gloria Grande' cross had high levels of resistance (Table 2). This points out that 'Gloria Grande' is an extremely good parent, especially when considering the susceptibility of the other parent ('Wichita'). 'Gloria Grande' likely would produce an even higher proportion of resistant progeny if crossed with parents with intermediate resistance (e.g., 'Pawnee'). The midparent value of this cross was not as low (resistant) as some others. The lowest midparent value (2.35) was for the crosses 'Pawnee' $x$ 'Osage' and 'Osage' $x$

Table 2. Scab resistance of families compared to midparent values. Ratings made according to the scale of Hunter and Roberts (1978), where class $1=$ most resistant.

\begin{tabular}{lcccc}
\hline $\begin{array}{l}\text { Cross } \\
\text { (female } \times \text { male) }\end{array}$ & $\begin{array}{c}\text { No. } \\
\text { progeny/ } \\
\text { family }\end{array}$ & $\begin{array}{c}\text { Progeny } \\
\text { mean }\end{array}$ & $\begin{array}{c}\text { \% Progeny } \\
\text { acceptable } \\
\text { (class 1 or 2) }\end{array}$ & Midparent \\
\hline Pawnee $\times$ Wichita & \\
Wichita $\times$ Cherokee & 52 & $3.90 \mathrm{a}^{\mathrm{y}}$ & 30.8 & 3.75 \\
Wichita $\times$ Choctaw & 242 & $3.87 \mathrm{ab}$ & 17.8 & 4.50 \\
Wichita $\times$ Pawnee & 10 & $3.80 \mathrm{ab}$ & 50.0 & 3.35 \\
Shawnee $\times$ Cheyenne & 189 & $3.79 \mathrm{ab}$ & 17.5 & 3.75 \\
Cherokee $\times$ Wichita & 39 & $3.54 \mathrm{a}-\mathrm{c}$ & 43.6 & 3.25 \\
Osage $\times$ Wichita & 21 & $3.52 \mathrm{a}-\mathrm{c}$ & 28.6 & 4.50 \\
Cheyenne $\times$ Choctaw & 33 & $3.48 \mathrm{a}-\mathrm{c}$ & 56.7 & 3.60 \\
Pawnee $\times$ Osage & 19 & $3.37 \mathrm{a}-\mathrm{c}$ & 26.3 & 2.60 \\
Pawnee $\times$ Cheyenne & 20 & $3.35 \mathrm{a}-\mathrm{d}$ & 45.0 & 3.35 \\
Cheyenne $\times$ Pawnee & 48 & $3.04 \mathrm{~b}-\mathrm{e}$ & 31.2 & 3.00 \\
Cheyenne $\times$ Osage & 150 & $2.91 \mathrm{c}-\mathrm{e}$ & 47.3 & 2.85 \\
Tejas $\times$ Cheyenne & 12 & $2.83 \mathrm{c}-\mathrm{e}$ & 50.0 & 3.75 \\
Osage $\times$ Pawnee & 11 & $2.54 \mathrm{de}$ & 54.5 & 2.35 \\
Wichita $\times$ Gloria Grande & 46 & $2.54 \mathrm{de}$ & 56.5 & 3.00 \\
Total no. & 24 & $2.33 \mathrm{e}$ & 66.6 & 3.62 \\
Mean & 916 & & & \\
\hline
\end{tabular}

${ }^{2}$ Underlined pedigrees indicate reciprocal crosses.

'Means with a common letter are not significantly different, Duncan's multiple range test $(\alpha \leq 0.05)$.

'Pawnee'. These crosses together produced 53\% highly resistant progeny. Crosses between two susceptible parents (i.e., 'Wichita' x 'Cherokee') produced at least some resistant progeny. This possibly results from some recessive and/or complementary gene action. It may indicate that the highly desirable yield and nut quality attributes of 'Wichita' can be genetically combined with high scab resistance to produce superior new cultivars for humid climates. 'Wichita', one of the most precocious and productive cultivars, is unacceptable for such areas due to its severe scab susceptibility. Scab resistance in these crosses needs to be monitored over time to determine if the durability of resistance is influenced by parentage.

No maternal differences for scab resistance were observed in the three sets of reciprocal crosses (Table 2). Therefore, in breeding for scab-resistant pecans, crosses can be made with either parent as female. If other traits are cytoplasmically inherited, they might dictate the choice of maternal parent. For example, Hanna (1972) noted patterns of nutrient accumulation in seedlings of reciprocal crosses, which suggested considerable cytoplasmic influence on inheritance.

Heritability values obtained by regressing the 948 progeny on parental values indicated that the overall mean of the ratings for females was slightly higher than that of the males (Table 3). Ratings for females and males, when used separately and regressed with the

Table 3. Heritability values and other statistics for pecan scab ratings $(n=948)$.

\begin{tabular}{lccc}
\hline \hline Source & $\begin{array}{c}\text { Mean } \\
\text { rating }\end{array}$ & $\mathrm{h}^{2}$ & $\begin{array}{c}\mathrm{CV} \\
(\%)\end{array}$ \\
\hline Progeny & 3.44 & & \\
Female & 4.01 & $0.496^{* * * *}$ & 38.7 \\
Male & 3.23 & $0.476^{* * * *}$ & 38.8 \\
Midparent & 3.62 & $0.540^{* * * *}$ & 37.9 \\
\hline${ }_{* * * * *}^{*}$ St
\end{tabular}

${ }^{* * * *}$ Statistically significant at $\alpha \leq 0.0001$ using the $t$ test. individual progeny values, gave medium heritability estimates. The $\mathrm{h}^{2}$ value using the midparent values was somewhat higher and shows that good progress likely would be made by selecting parents on the basis of their phenotype.

Breeding scab-resistant cultivars should start with the selection of parents having high levels of scab resistance and other desirable horticultural traits, since the proportion of resistant progeny is a function of midparent resistance. Regardless of the level of parental resistance, progeny must be screened for scab resistance because most families include individuals at each level. Selecting seedlings with class 1 or class 2 levels of nut scab likely will assure the identification of future cultivars with useful levels of resistance. If continued research indicates that durability of resistance over time is also influenced by parental resistance, the emphasis on parental selection needs to be increased.

\section{Literature Cited}

Cole, J.R. and A.C. Gossard. 1956. Increased virulence of scab (Cladosporium effusum Wint.) Demaree) on Stuart pecan in Mississippi and its presence in Louisiana. Plant Dis. Rptr. 40:1120.

Crane, H.L., C.A. Reed, and M.N. Wood. 1937. Nut breeding. U.S. Dept. Agr. Yrbk. Agr. 1937:827889.

Demaree, J.B. 1924. Pecan scab with special reference to sources of the early spring infections. J. Agr. Res. 28(4):321-333.

Demaree, J.B. and J.R. Cole. 1929. Behavior of Cladosporium effusum (Wint.) Demaree on some varieties of pecan. J. Agr. Res. 18:363-370.

Hanna, J.D. 1972. Absorption and accumulation of chloride ions by pecan (Carya illinoensis Koch) seedling rootstocks. PhD Diss., Texas A\&M Univ., College Station.

Hunter, R.E. and D.D. Roberts. 1978. A disease grading system for pecan scab. Pecan Quarterly 12(3):3-6.

Kempthorne, O. and O.B. Tandon. 1953. The estimation of heritability by regression of offspring on parent. Biometrics 9:90-100. 


\section{Breeding, Cultivars, Rootstocks, \& Germplasm Resources}

KenKnight, G. 1969. Dissemination of pathogenic races of the pecan scab fungus, Cladosporium effusum, by mechanical harvesting. Plant Dis. Rptr. 53:710.

Latter, B.D.H. and A. Robertson. 1960. Experimental design in the estimation of heritability by regression methods. Biometrics 16:348-352.

Roberts, D.D., R.E. Hunter, and D.C. Campbell. 1977. Breeding for resistance to pecan scab. Proc. Texas Pecan Growers Assn. 56:58-60.
Sanderlin, R.S. 1992. Survey of Louisiana pecan orchards for scab pathogen populations tolerant to benomyl fungicide. Proc. Southeastern Pecan Growers Assn. 85:123-127.

SAS Institute. 1985. SAS procedures guide for personal computers, version 6 edition. SAS Inst., Cary, N.C.

Smith, C.L. and L.D. Romberg. 1940. Stigma receptivity and pollen shedding in some pecan varieties. J. Agr. Res. 60(8):551-564.
Street, J.E. 1972. Fusicladium effusum: Pathogenicity, host screening, and mode of genetic variation; and pecan tissue culture. MS Thesis, Mississippi State Univ., Mississippi State.

Thompson, T.E. and L.J. Grauke. 1991. Pecans and other hickories (Carya), p. 839-903. In: J.N. Moore and J.R. Ballington (eds.). Genetic resources of temperate fruit and nut crops. Intl. Soc. Hort. Sci., Wageningen, The Netherlands. 